\title{
TECHNO-ECONOMIC EVALUATION OF LANDFILL LEACHATE TREATMENT BY HYBRID LIME APPLICATION AND NANOFILTRATION PROCESS
}

\section{Ronei de Almeida *, Fábio de Almeida Oroski and Juacyara Carbonelli Campos}

School of Chemistry, Federal University of Rio de Janeiro, 149 Athos da Silveira Ramos Avenue, room E206, 21941-909, Rio de Janeiro, Brazil

Article Info:
Received:
8 June 2019
Revised:
15 December 2019
Accepted:
13 January 2020
Available online:
29 January 2020
Keywords:
Leachate
Lime
Air stripping
Nanofiltration
Hybrid process
Cost estimation

Article Info:

Received:

8 June 2019

15 December 2019

Accepted:

13 January 2020

Keywords:

Leachat

Air stripping

Hybrid process

Cost estimation

\begin{abstract}
Leachate treatment is a major issue in the context of landfill management since solutions have not been yet developed, resulting in more satisfactory technical and economic results concerning leachate treatment. In this paper, the technical and economic factors concerning lime application and nanofiltration for the treatment of leachate from the Seropédica landfill (Rio de Janeiro State, Brazil) were evaluated. The results indicate that the application of $30 \mathrm{~g}$ lime $\mathrm{L}^{-1}$, under optimum conditions, followed by air stripping, was able to place the effluent within the ammonia nitrogen discharge standard imposed by local legislation. The use of nanofiltration produced a clear and colorless permeate and has proved to be very effective at removing all pollutants. Regarding cost estimates, considering a means leachate generation flow of $1000 \mathrm{~m}^{3}$, recovery of $60 \%$ and average permeate flux of $12 \mathrm{~L} \mathrm{~m}^{-2} \mathrm{~h}^{-1}$. The total cost per $\mathrm{m}^{3}$ of treated effluent was estimated in two scenarios, using different types of membrane and therefore different membrane costs per $\mathrm{m}^{2}$. Considering that the landfill would operate for 25 years and after closing, the leachate treatment station would maintain its activities for another 15 years, totaling 40 years, the cost to treat leachate would be of US\$ 10.54 and US\$ $11.33 \mathrm{~m}^{-3}$. In both evaluated scenarios, with regard to process operation costs, the percentage value relative to membrane exchange was emphasized. It is noteworthy that, a treated effluent at a lower cost to that currently presented by the landfill was obtained through the applied hybrid process.
\end{abstract}

\section{INTRODUCTION}

Considering the high concentration of pollutants and varying composition influenced by the type of waste, landfill age, and geological conditions, leachate treatment is undeniably one of the most challenging tasks in municipal solid waste management (Kjeldsen et al., 2002; Zhang et al., 2019). Landfill leachate contains high loads of organic matter, inorganic salts (sulfates, carbonates, and sodium chloride), ammonia, and halogenated and heavy metals that must be treated before being released into the environment (Kjeldsen et al., 2002). According to the literature, critical parameters for most landfills are chemical oxygen demand and ammoniacal nitrogen $\left(\mathrm{NH}_{3}-\mathrm{N}\right)$ (Ehrig and Robinson, 2010). Although many methods may apply, the most appropriate leachate treatment choice will depend on its features, technical applicability, cost-effectiveness, and other factors related to the quality requirements of the effluents.

Main classification of the technical solution and technology classification for leachate management and treatment on the site or at the leachate treatment plant could be divided into following groups: leachate treatment on the site or transfer to the central wastewater treatment plant (leachate lagoons and recirculation into the landfill body or at the surface, combined leachate with the domestic sewage system and treatment at the wastewater treatment plant), biological processes (different combination of the aerobic and anaerobic processes), physicochemical processes (chemical oxidation, adsorption on activated carbon, chemical precipitation, coagulation-flocculation, air stripping) and membrane processes (main reverse osmosis and nanofiltration) (Ehrig and Robinson, 2010; Schiopu et al., 2012; Serdarevic, 2018; Yao, 2013). The conventional biological process could be effective for the removal of organic biodegradable substances, suspended solids and nutrients (Metcalf et al., 2003; Zhao and Zyyang, 2019). With time, the major presence of refractory compounds (mainly humic and fulvic acids) contribute to limit 
the process's effectiveness (Rodrigues et al., 2009; Talalaj et al., 2019). Therefore, for the removal of recalcitrant compounds, advanced treatment processes such as physicochemical and membrane technologies are required (Renou et al., 2008; Talalaj et al., 2019; Zawierucha et al., 2013).

Coagulation-flocculation may be used successfully in treating stabilized and old landfill leachates. It is widely used as a pre-treatment, prior to biological or nanofiltration step, or as a final polishing treatment step in order to remove non-biodegradable organic matter (Amaral et al. 2016; Amokrane et al., 1997; Amor et al., 2015). On the other hand, one option for reducing $\mathrm{NH}_{3}-\mathrm{N}$ concentrations is the stripping of ammonia gas. At raised $\mathrm{pH}$ values or temperatures, an increased proportion of the total ammoniacal- $\mathrm{N}$ (ammonium + ammonia) is present as gaseous ammonia (Campos et al., 2013; Metcalf et al., 2003). During intensive contact with gases (e.g. with air) concentrations of dissolved ammonia gas adjust to an equilibrium between liquid and gaseous phases. Using this effect ammonia can be stripped from the liquid within the gas stream (Ehring and Robinson, 2010; Metcalf et al., 2003). Pretreatment by lime application, therefore, appears as a promising approach by combining the coagulation-flocculation process and favoring the raised of the $\mathrm{pH}$ of the leachate favoring, subsequently, the $\mathrm{NH}_{3}-\mathrm{N}$ stripping by airflow.

In the last decades, nanofiltration (NF) has been widely used in landfill leachate treatment (Zhao and Zyyang, 2019). The advantage of using NF membrane is that its request for lower operating pressures and energy consumption $\left(10 \mathrm{kWh} \mathrm{m}^{-3}\right)$, has higher fluxes than reverse osmosis (RO) membranes, better retention than an ultrafiltration (UF) membrane, high rejection of polyvalent ions and organic with molecular weight above $300 \mathrm{Da}$, relatively low investment and has low operational and maintenance costs. Moreover, due to its unique properties as compared to UF and RO membranes, the NF membrane has an important advantage that is the ability to remove recalcitrant organic compounds and heavy metals in leachate (Kwon et al., 2008; Chaudhari and Murthy, 2010).

The costs for treatment of leachate vary from simpler processes such as co-treatment with sewage (about $18-27 € \mathrm{~m}^{-3}$ ) to more sophisticated technologies such as reverse osmosis (15-40 $€ \mathrm{~m}^{-3}$ ) (Calabro et al., 2018; Robinson, 2005). Brazilian researchers have highlighted the need to use efficient and economically viable technologies for the treatment of leachate in Brazilian landfills (Amaral et al., 2015; Amaral et al., 2016; De Almeida et al., 2019). However, to the best of our knowledge, the most advanced leachate treatment technologies are not feasible in most of the municipalities due to, for instance, the high cost of implementation and maintenance, and the volumes of leachate to be treated. Consequently, municipalities are required to implement treatment processes that are incompatible with the characteristics of the leachate, resulting in a treated effluent on disagreement with established disposal legislation. In this context, the objective of the present study is, therefore, to evaluate the technical and economic factors concerning hybrid lime application and nanofiltration treatment of leachate from the Seropédica landfill, located in Rio de Janeiro State (Brazil).

\section{MATERIALS AND METHODS}

\subsection{Leachate characterization}

The leachate utilized for the experiments was provided by the COMLURB (Municipal Urban Cleaning Company, Rio de Janeiro city) of the Seropédica landfill, located in Rio de Janeiro - Brazil, in September 2017. The Seropédica landfill received in recent years approximately 10000 tonnes per day of waste and currently generates $1000 \mathrm{~m}^{3}$ leachate per day.

The characterization of the leachate was based on the following parameters and methods recommended by American Public Health Association (APHA, 2012): potential of hydrogen $(\mathrm{pH})$, Chemical Oxygen Demand - COD (5220-D), ammonium nitrogen $-\mathrm{NH}_{3}-\mathrm{N}$ (4500-E), true-color (2120-C) chloride- $\mathrm{Cl}^{-}\left(4500-\mathrm{Cl}^{-}\right)$, conductivity, turbidity, and absorbance at $254 \mathrm{~nm}$ (5910-B), it provides an indication of the content of aromatic organic matter and humic substances (APHA, 2012). The concentration of humic substances (humic and fulvic acids) were determined by the modified spectrophotometric/colorimetric method, based on the binding of toluidine blue dye (TB) with humic acid molecules to produce a dye-humic acids complex that causes the decrease in absorbance at $603 \mathrm{~nm}$ (Lima et. al., 2017).

\subsection{Leachate treatment}

\subsubsection{Lime application}

Jar tests were conducted to determine the optimum dosage of lime to be used before the final step of treatment by nanofiltration. The lime was added as "lime milk" (at 200 $\mathrm{g} \mathrm{L}^{-1}$ of lime), in $500 \mathrm{~mL}$ beakers and its concentration after addition ranged from 10 to $50 \mathrm{~g} \mathrm{~L}^{-1}$. After the lime had been added, coagulation-flocculation (C-F) was achieved by rapid stirring (150 rpm) for $1 \mathrm{~min}$ followed by slow stirring (50 $\mathrm{rpm}$ ) for $30 \mathrm{~min}$. The suspension was, then, allowed to settle for $30 \mathrm{~min}$. The operational condition stirring employed in $\mathrm{C}-\mathrm{F}$ was based on reports in the literature (Aziz et al., 2007; Lima et al., 2017; Renou et al., 2008; Renou et al., 2009). At the end of the decantation step, samples of supernatant phases were collected to be analyzed.

At optimum lime dose, the sobrenadant was aerated through an air compressor (Boyu S-500A model) at a flow rate of $1.33 \mathrm{~L}$ of air $\mathrm{min}^{-1}$ per liter of effluent. In a period of $12 \mathrm{~h}$, samples were collected every $1 \mathrm{~h}$ to evaluate the $\mathrm{COD}$ and $\mathrm{NH}_{3}-\mathrm{N}$ concentration of the effluent and after $24 \mathrm{~h}$, the same parameters were analyzed. The operational condition of the air stripping was based on reports described by Campos et al. (2013).

The removal efficiency $(E(\%))$ of the pollution parameters was defined by Equation 1.

$E(\%)=100 \times\left(\left(C_{0}-C\right) / C_{0}\right)$

Where, $\mathrm{C}_{0}$ is the concentration of the pollution parameter of raw leachate and $C$, the concentration of the pollution parameter of treated effluent.

\subsubsection{Nanofiltration}

Nanofiltration (NF) was performed using a bench-scale filtration module. The experimental system consisted of a heated feed tank, a membrane module, a pressure gauge, 
a recirculation pump (B-01), flow meters ( $\mathrm{Fl}-01$ and $\mathrm{FI}-02)$, flow control valves in the feed $(\mathrm{V}-1)$, permeate $(\mathrm{V}-3, \mathrm{~V}-4)$ and concentrate streams ( $\mathrm{V}-2)$ (Figure 1$)$. The system has a capacity of $5.0 \mathrm{~L}$, an effective circular membrane area of $77.7 \mathrm{~cm}^{2}$, the material of construction of 316 stainless steel cells (PAM Selective Membranes Inc.).

The leachate was tested with two polymer membrane models: SR100, consisting of polyamide and nominal retention of $200 \mathrm{Da}$ and NP030, consisting of polyethersulfone and nominal retention of $400 \mathrm{Da}$. Previously, permeate flux $\left(J, \mathrm{~L} \mathrm{~m}^{-2} \mathrm{~h}^{-1}\right)$ measurements were performed as a function of the operating pressure (7 and 8 bar) and the recirculation flow rate $\left(30,60,90120 \mathrm{~L} \mathrm{~h}^{-1}\right)$. Subsequently, under ideal conditions of operation, the system was fed with 3.0 liters of leachate pretreated by the physicochemical process. The operating conditions have been defined by the system's technical constraints.

The volume reduction factor (VRF) was used to describe the extent of concentration in the NF unit during filtration. VRF was calculated using Equation 2.

$V R F=V f / V c$

Where $\mathrm{Vf}$ and $\mathrm{Vc}$ are the initial volumes of the NF feed and the volume of NF concentrate produced, respectively, both measured in $\mathrm{L}$.

During testing, the valves $\mathrm{V}-2$ and $\mathrm{V}-4$ remained opened, valve $\mathrm{V}-3$ was closed and the feed flow rate and pressure were controlled by the frequency inverter connected to the pump B-01 and through the valve $\mathrm{V}-1$. The permeate was collected and conditioned at $4^{\circ} \mathrm{C}$. At the end of the filtration step, samples of permeate were collected to be analyzed. All the experiments were performed in triplicate.

\subsubsection{Hybrid process}

After the establishment of the ideal operating conditions of the lime application and nanofiltration process, the

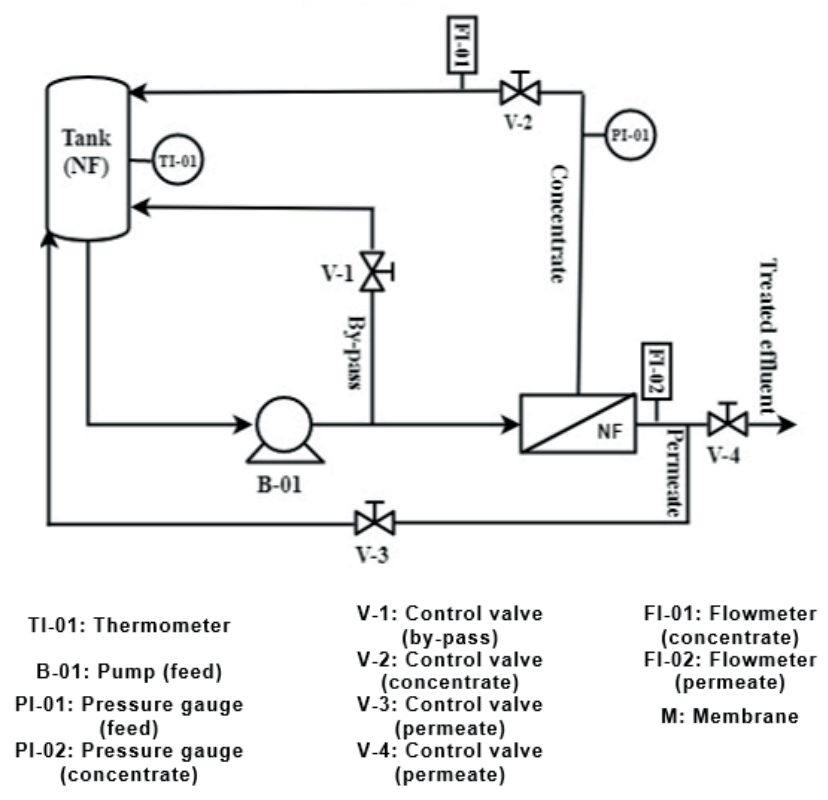

FIGURE 1: Schematic diagram of the nanofiltration experimental setup. hybrid treatment proposed in this study was operated in order to jointly evaluate the removal efficiency of the liquid effluent pollution parameters described in item 2.1.

\subsection{Cost estimation}

The cost estimation was performed based on the results obtained in the tests in filtration module and extrapolated to a real system with pre-defined leachate treatment flow, being represented, in this work, by the capital expenditure (CAPEX), by the operational expenditure (OPEX) and total cost (TC) normalized per unit volume of treated leachate. For preliminary estimation of costs of the hybrid process, the following considerations were made:

(a) The value of the capital cost of the lime treatment process was estimated from the study presented by Silva et al. (2011). The authors estimated the cost of implantation of the lime application process, considering the implantation of tanks, pumps, blowers, valves and pipes, civil construction and a feed flow of 1000 $\mathrm{m}^{3}$.day ${ }^{-1}$, as proposed in this work;

(b) Treatment and final disposal of the sludge and the concentrate generated in the process were not considered since these wastes can be disposed of in the landfill itself without additional costs for the leachate treatment plant;

(c) The leachate treatment plant would operate 365 days a year and would be out of operation only during periods of routine maintenance, chemical cleaning and integrity testing (Guerra and Pellegrino, 2012);

(d) The nanofiltration process plant would operate with $60 \%$ efficiency (Amaral et al., 2016);

(e) The membrane spiral modules used would be $1.016 \mathrm{~m}$ long, $0.2 \mathrm{~m}$ in diameter and $40 \mathrm{~m}^{2}$ in working area (Baker, 2012);

(f) The preliminary cost of the process was estimated considering the cost of the $\mathrm{m}^{2}$ of the polymer membrane of US\$ 40.00 (Baker, 2012; Guerra and Pellegrino, 2012) and US\$ 180.00 (Amaral et al., 2016).

CAPEX was determined by adding up the acquisition costs of the membrane modules, housing, valves, pipes and instrumentation that constitute a permeation unit (Salehi et al., 2014; Singh and Cheryan, 1998). The startup cost which is the amount of capital required to start the operation, corresponding to $8 \%$ of fixed investment, was also considered as an investment cost.

For the composition of OPEX, the costs of energy consumption for the operation of the nanofiltration system, investment depreciation, membrane exchange, maintenance, hand labor, and membrane regeneration were included (Singh and Cheryan, 1998). The energy consumption was estimated at $20.7 \mathrm{~kW}$ (496.8 kWh, given continuous for 24 $\mathrm{h}$ day $^{-1}$ operations) with $0.5 \mathrm{~kW}$ used to coagulation-flocculation, $1.5 \mathrm{~kW}$ to aeration during air stripping, $3.7 \mathrm{~kW}$ to sludge recirculation and $15 \mathrm{~kW}$ for NF system. For the maintenance cost, a value of $5 \%$ of the initial investment associated with preventive and corrective maintenance of the membrane was considered. As an estimated cost of chemicals used to clean the membranes, a value of $2 \%$ of 
the initial investment was considered (Amaral et al., 2016).

The TC per unit volume of treated leachate was obtained by Equation 3, which accounts for the OPEX normalized by annual volume of treated effluent and the CAPEX normalized by volume of treated effluent added annually to the time, in years, of operation of the nanofiltration process, determined by means of Equation 4 .

$$
\begin{aligned}
& T C=R_{\text {CAPEX }}+O P E X / V_{T} \\
& R_{\text {CAPEX }}=C A P E X / V_{T} n
\end{aligned}
$$

Where,

$R_{\text {CAPEX }}$ : normalized capital cost per volume of treated effluent (US\$ $\left.\mathrm{m}^{-3}\right)$; $\mathrm{n}$ : operating period of the leachate treatment plant considered in years; $\mathrm{V}_{\mathrm{T}}$ : total volume of treated effluent $\left(m^{3}\right)$.

\section{RESULTS AND DISCUSSION}

\subsection{Leachate characterization}

Table 1 shows the values of the parameters obtained in the characterization of the raw leachate used in this study.

Leachate samples were slightly alkaline with dark color, eventually brown, and showed a high concentration of ammoniacal nitrogen $\left(1512 \pm 239 \mathrm{mg} \mathrm{L}^{-1}\right)$. The presence of $\mathrm{NH}_{3}-\mathrm{N}$ in landfill leachates represents a risk of surface and groundwater pollution. Dregs with a high concentration of ammoniacal nitrogen released into water bodies without previous treatment can cause eutrophication, depletion of dissolved oxygen and toxic effects on aquatic fauna (Metcalf et al., 2003; Postacchinine et al. 2018).

The HS/COD (0.32) ratio also supports the assumption that the leachate has a high concentration of recalcitrant organic compounds (Lima et al., 2017), so the conventional treatments have limited efficiency when used to treat the leachate. Moreover, the ratio between biodegradable COD and $\mathrm{NH}_{3}-\mathrm{N}$ should be greater than four for the completion of the nitrate denitrification in biological processes (Talalaj and Biedka, 2015). This effluent is also characterized

TABLE 1: Parameters obtained in the characterization of the raw

\begin{tabular}{|c|c|c|c|c|}
\hline Parameters & Min & Max & Average $\pm \sigma_{\mathrm{M}}$ & $\sigma$ \\
\hline $\mathrm{pH}$ & 7.7 & 8.2 & $8.0 \pm 0.1$ & 0.1 \\
\hline $\operatorname{COD}\left(\mathrm{mg} \mathrm{L}^{-1}\right)$ & 4330 & 4690 & $4522 \pm 28$ & 90 \\
\hline $\mathrm{HS}\left(\mathrm{mg} \mathrm{L}^{-1}\right)$ & 1238 & 1678 & $1466 \pm 151$ & 120 \\
\hline $\mathrm{NH}_{3}-\mathrm{N}\left(\mathrm{mg} \mathrm{L}^{-1}\right)$ & 1150 & 1851 & $1512 \pm 76$ & 239 \\
\hline Abs $254 \mathrm{~nm}$ & 26.29 & 27.01 & $26.70 \pm 0.03$ & 0.10 \\
\hline True color (mg Pt-Co L-1) & 5560 & 7640 & $6391 \pm 190$ & 602 \\
\hline Conductivity ( $\mathrm{mS} \mathrm{cm}^{-1}$ ) & 15 & 20 & $19 \pm 1$ & 4 \\
\hline Turbidity (NTU) & 110 & 120 & $110 \pm 5$ & 15 \\
\hline $\mathrm{Cl}^{-}$ & 890 & 1327 & $887 \pm 90$ & 67 \\
\hline
\end{tabular}
leachate $(n=10)$.

$\sigma=\sqrt{\frac{\sum_{i=1}^{n}(M-\bar{M})^{2}}{n-1}} ; \sigma_{M}=\frac{\sigma}{\sqrt{n}}$

$\sigma=$ standard desviation; $M$ = test value; = average value; $\mathrm{n}$ = number of tests; $\sigma_{M}=$ standard desviation of the mean

$\mathrm{pH}$ : potential of hydrogen; COD: Chemical Oxygen Demand; HS: Humic

Substance; Abs 254 nm: Absorbance at $254 \mathrm{~nm}$; $\mathrm{NH}_{3}-\mathrm{N}$ : ammoniacal nitrogen; $\mathrm{Cl}-$ : Chloride. by a very high content in dissolved salts, notably chlorides $\left(887 \pm 67 \mathrm{mg} \mathrm{L}^{-1}\right)$ and conductivity $\left(19 \pm 4 \mathrm{Ms} \mathrm{cm}^{-1}\right)$.

Ahmed and Christopher (2012) reported that the composition of leachate and the concentrations of contaminants are influenced by the type of waste deposited and the age of the landfill. In this case, high concentrations of recalcitrant organic matter and $\mathrm{NH}_{3}-\mathrm{N}$ may be justified as a result of the characteristics of the waste deposited in the landfill and consequence of the biological degradation of amino acids and other organic nitrogen compounds.

\subsection{Leachate treatment}

\subsubsection{Lime application}

The coagulation-flocculation process was performed to reduce the concentration of recalcitrant organic matter (humic substances). This stage was a pretreatment of the effluent, conditioning the leachate for the subsequent process of air stripping and nanofiltration. The results of the assays performed at concentrations of 10 to $50 \mathrm{~g} \mathrm{~L}^{-1}$ lime, 1 min rapid mixing at $150 \mathrm{rpm}, 30$ min slow mixing at $50 \mathrm{rpm}$ and decanting for 30 minutes are shown in Table 2 .

As can be observed, larger COD removal was obtained in a concentration of $40 \mathrm{~g} \mathrm{~L}^{-1}$ of lime (56\%), while the highest percentage of $\mathrm{HS}$ removal was obtained in a concentration of $30 \mathrm{~g}$ lime $\mathrm{L}^{-1}$ (42\%). Comparatively, in this last coagulant concentration, considering the standard deviation, the percentage of COD removal (48\%) was close to that obtained in higher concentrations of lime. Additionally, this lime concentration also corresponded to the lowest conductivity value obtained for the treated effluent $(13 \pm 1$ $\mathrm{mS} \mathrm{cm}{ }^{-1}$ ).

According to Renou et al. (2009), lime addition seems to have various effects on leachate. The lime pretreatment induces the leachate decarbonation, which has a strong effect on its inorganic fraction. While lime is being added, the carbonate ions precipitate massively and it results in a decrease in conductivity. Conductivity decreases until the carbonate concentration becomes limiting and prevents the solubility limit of this salt from being exceeded. At this point, the lime dose is considered optimum (within the assessed range) and corresponds to a maximum reduction of conductivity.

According to Lima et al. (2017), physical-chemical treatments show satisfactory results in terms of the removal of recalcitrant compounds (mainly monitored by color and absorbance at $254 \mathrm{~nm}$ ) present in the leachate samples. Although lime application has been traditionally used to overcome temporary water hardness by a decarbonating process, a number of studies have been effective to remove some organic molecules of high molecular weight such as humic and fulvic acids (Amaral et al., 2015; Chen et al., 2017; El-Gohary et al., 2013; Renou et al., 2009).However, in general, the introduction of chemical agents leads to an increase in the concentration of salts in the effluent, therefore, the further treatment process is needed.

In the optimum concentration of lime $\left(30 \mathrm{~g} \mathrm{~L}^{-1}\right)$, the removal of $\mathrm{NH}_{3}-\mathrm{N}$ and COD was evaluated under the conditions described in item 2.2.1. Figure 2 shows the concen- 
TABLE 2: Parameters obtained for determination of the optimum lime concentration for the coagulation-flocculation process in the concentration of 10 to $50 \mathrm{~g}$ lime $\mathrm{L}^{-1}$, rapid mixing of $1 \mathrm{~min}$ at $150 \mathrm{rpm}$, slow mixing for $30 \mathrm{~min}$ at $50 \mathrm{rpm}$ and decantation by 30 min ( $\mathrm{n}=3$ ).

\begin{tabular}{|c|c|c|c|c|c|c|c|c|c|}
\hline \multicolumn{10}{|c|}{ Parameters } \\
\hline $\begin{array}{l}\text { Lime } \\
\left(g \cdot L^{-1}\right)\end{array}$ & $\mathrm{pH}$ & $\begin{array}{c}\text { COD } \\
\left(\mathrm{mg} \mathrm{L}^{-1}\right)\end{array}$ & $\begin{array}{c}\mathrm{HS} \\
\left(\mathrm{mg} \mathrm{L}^{-1}\right)\end{array}$ & $\begin{array}{c}\text { ABS } \\
254 \mathrm{~nm}\end{array}$ & $\begin{array}{c}\mathrm{NH}_{3}-\mathrm{N} \\
\left(\mathrm{mg} \mathrm{L}^{-1}\right)\end{array}$ & $\begin{array}{c}\text { True color } \\
\left(\mathrm{mg} \mathrm{Pt}^{\left.-\mathrm{Co} \mathrm{L}^{-1}\right)}\right.\end{array}$ & $\begin{array}{l}\text { Conductivity } \\
\left(\mathrm{mS} \mathrm{cm}^{-1}\right)\end{array}$ & $\begin{array}{c}\mathrm{Cl}^{-} \\
\left(\mathrm{mg} \mathrm{L}^{-1}\right)\end{array}$ & $\begin{array}{l}\text { Turbidity } \\
\text { (NTU) }\end{array}$ \\
\hline $\begin{array}{c}\text { Raw } \\
\text { leachate }\end{array}$ & $8.0 \pm 0.1$ & $4522 \pm 452$ & $1466 \pm 151$ & $26.70 \pm 0.03$ & $1512 \pm 148$ & $6391 \pm 640$ & $19 \pm 2$ & $887 \pm 80$ & $110 \pm 12$ \\
\hline 10 & $8.0 \pm 0.1$ & $3165 \pm 315$ & $1180 \pm 120$ & $22.30 \pm 0.02$ & $1120 \pm 119$ & $5875 \pm 588$ & $16 \pm 2$ & $766 \pm 77$ & $105 \pm 11$ \\
\hline 20 & $8.5 \pm 0.1$ & $3210 \pm 320$ & $1298 \pm 130$ & $18.87 \pm 0.02$ & $1098 \pm 101$ & $5760 \pm 576$ & $16 \pm 2$ & $754 \pm 75$ & $87 \pm 9$ \\
\hline 30 & $9.1 \pm 0.1$ & $2344 \pm 240$ & $855 \pm 87$ & $13.78 \pm 0.01$ & $1310 \pm 126$ & $1560 \pm 140$ & $13 \pm 1$ & $562 \pm 56$ & $54 \pm 5$ \\
\hline 40 & $9.6 \pm 0.1$ & $1995 \pm 200$ & $990 \pm 101$ & $15.60 \pm 0.02$ & $996 \pm 93$ & $2230 \pm 230$ & $15 \pm 2$ & $495 \pm 50$ & $48 \pm 5$ \\
\hline 50 & $9.8 \pm 0.1$ & $3220 \pm 321$ & $1005 \pm 110$ & $10.57 \pm 0.01$ & $1078 \pm 101$ & $995 \pm 100$ & $19 \pm 2$ & $568 \pm 61$ & $52 \pm 5$ \\
\hline
\end{tabular}

trations of $\mathrm{NH}_{3}-\mathrm{N}, \mathrm{COD}$ and the respective percentages of removal efficiency along the air stripping process.

It is important to stress that, the airflow entrainment process in the operating conditions of $1.33 \mathrm{~L}$ air $\mathrm{min}^{-1}$ per liter of effluent and $24 \mathrm{~h}$ hydraulic retention time showed a removal efficiency of about $99 \%$ of ammoniacal nitrogen. The final $\mathrm{NH}_{3}-\mathrm{N}$ concentration of the effluent was approximately $9.8 \pm 1.0 \mathrm{mg} \mathrm{L}^{-1}$. According to Campos et al. (2013), when evaluating the removal of ammoniacal nitrogen from landfill leachate through the treatment with lime, as the alkalinity of the effluent decreases, there is a decrease in the concentration of ammoniacal nitrogen, due to the previous removal of $\mathrm{CO}_{2}$, which consequently favors the removal of $\mathrm{NH}_{3}-\mathrm{N}$ by stripping.

El-Gohary et al. (2013) carried out a study that evaluated the removal of ammoniacal nitrogen from landfill leachate by air stripping. Percent removal efficiency values of $94.5 \%$ were obtained after $24 \mathrm{~h}$ of stripping. The $\mathrm{pH}$ of

(a)

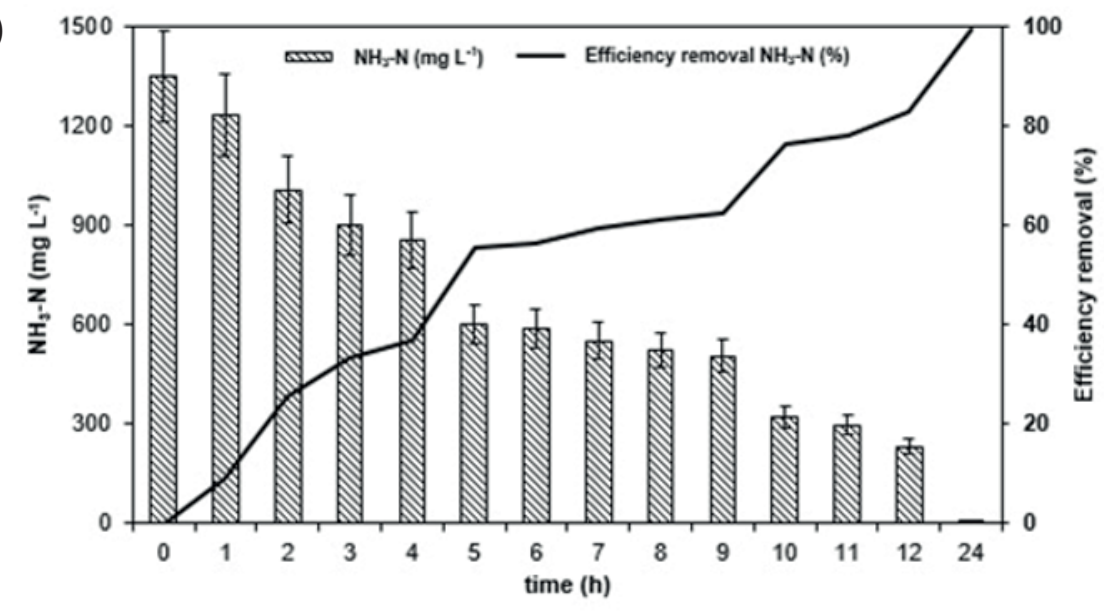

(b)

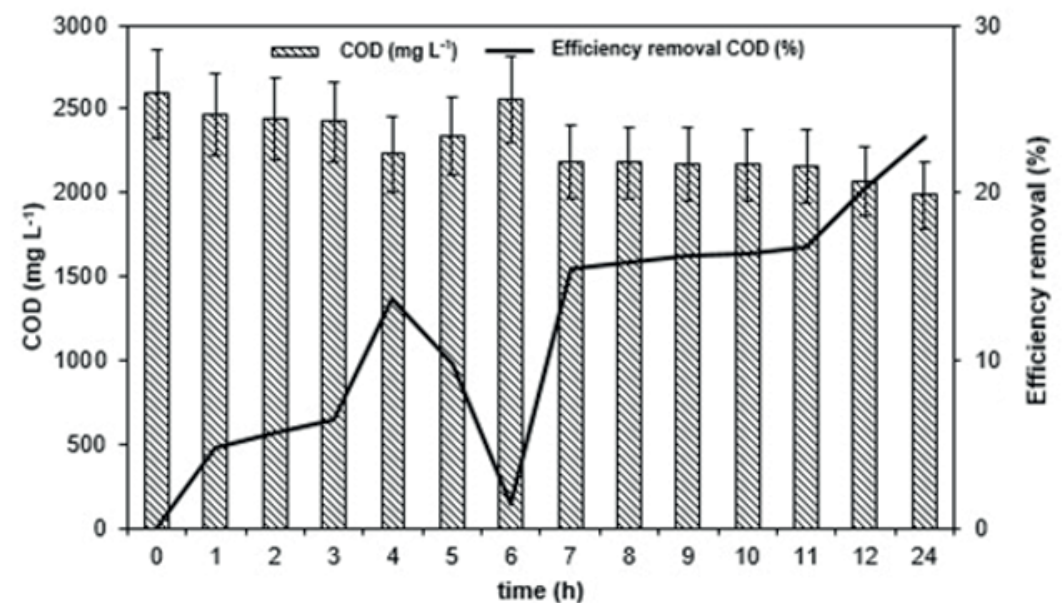

FIGURE 2: Concentration and efficiency of removal of $\mathrm{NH}_{3}-\mathrm{N}(\mathrm{a})$ and $\mathrm{COD}(\mathrm{b})$ as a function of the time of operation of the air stripping process ( $1.33 \mathrm{~L} \mathrm{~min}^{-1}$ per liter, $24 \mathrm{~h}$ retention time). 
the effluent at the end of the experiments was equal to 11 . According to the authors, after $6 \mathrm{~h}$ of air stripping, it was possible to observe a linear increase in the $\mathrm{pH}$ of the leachate (9-10) and at a hydraulic time of more than $6 \mathrm{~h}$, a significant increase in the percentage values of $\mathrm{NH}_{3}-\mathrm{N}$ removal. Thus, the authors concluded that $6 \mathrm{~h}$ of air stripping was sufficient to remove ammoniacal nitrogen from the leachate in considerable percentage terms of removal efficiency. On the other hand, in a study performed by Amaral et al. (2016), pretreatment by air stripping at $10 \mathrm{~m}^{3}$ reactor fed with raw leachate and hydraulic retention time of $48 \mathrm{~h}$, conducted at the natural $\mathrm{pH}(8.1)$, removed $65 \%$ of $\mathrm{NH}_{3}-\mathrm{N}$ present in the leachate.

An issue related to air stripping is that the ammonia passes to the gas phase, so the process must contain a collection system. Liu et al. (2014) presented an ammonia recovery efficiency to $80 \%$, using a solution of sulfuric acid $\left(1 \mathrm{~mol} \mathrm{~L}^{-1}\right)$. The authors comment that this solution can be used as a source of nitrogen for the manufacture of compounds that can be used as soil conditioning.

Additionally, in this study, it was decided to carry out an evaluation of the COD along with the air stripping, although this technology is not mentioned in the literature as the most appropriate for the removal of organic matter from the effluent. However, it was still observed that during the process, the COD concentration was reduced from $2590 \pm 250$ to $1987 \pm 190 \mathrm{mg} \mathrm{L}^{-1}$, about $23 \%$ removal efficiency. This percentage reduction in COD can be attributed to the fact that, during the aeration process of the effluent, colloid particles still present in the leachate are agglutinated and in a subsequent sedimentation process, this organic material is possibly removed (De Almeida et al., 2019).

It is worth noting that coagulant addition increased the particle size of suspended material. This, in turn, enhances the settling of suspended matter due to coagulation. Con- sequently, this will affect the removal of COD (Ismail et al., 2012). However, in time $6 \mathrm{~h}$ was observed a sharp decrease in COD removal efficiency. This may be justified due to the presence of suspended solids in the analyzed sample. One way to minimize possible measurement errors would be to perform sample filtration and quantify the filtered effluent COD (Golob et al., 2005).

\subsubsection{Nanofiltration}

Initially, for the two membranes used (SR100 and NP030), the permeate flux was evaluated with time, returning the permeate stream to the feed tank, at pressures of 7 and 8 bar, at a recirculation flow rate of $120 \mathrm{~L} \mathrm{~h}^{-1}$. The results are shown in Figure 3.

By the analysis of the permeate fluxes obtained during the filtration process of the membranes SR100 and NP030, it was verified that the permeated flux, in the two pressures evaluated, is higher in the NP030 membrane, this can be explained by comparing the nominal retention of the membranes, 200 Da for membrane SR100 and 400 Da for NP030. Sir et al. (2012) points out that the continuous decrease of the permeate flux along the membrane separation processes is also associated with other phenomena, such as the adsorption of humic and fulvic acids on the surface of the membrane, which can cause fouling of the membrane and lead to extremely low permeate fluxes, making the process unfeasible.

At the pressure of $7 \mathrm{bar}$, in the recycle flow rate evaluated, the permeate flux of the SR100 membrane oscillated between 11.6 and $10.3 \mathrm{~L} \mathrm{~m}^{-2} \mathrm{~h}^{-1}$, whereas for the NP030 membrane, this value was 16.0 at $15.7 \mathrm{~L} \mathrm{~m}^{-2} \mathrm{~h}^{-1}$. At higher pressure, the range of values was $13.5-12.9 \mathrm{~L} \mathrm{~m}^{-2} \mathrm{~h}^{-1}$ (SR100) and 17.4-16.1 $\mathrm{L} \mathrm{m}^{-2} \mathrm{~h}^{-1}$ (NP030).

Subsequently, the permeate flux was evaluated as a function of the recirculation flow, at pressures of 7 and 8

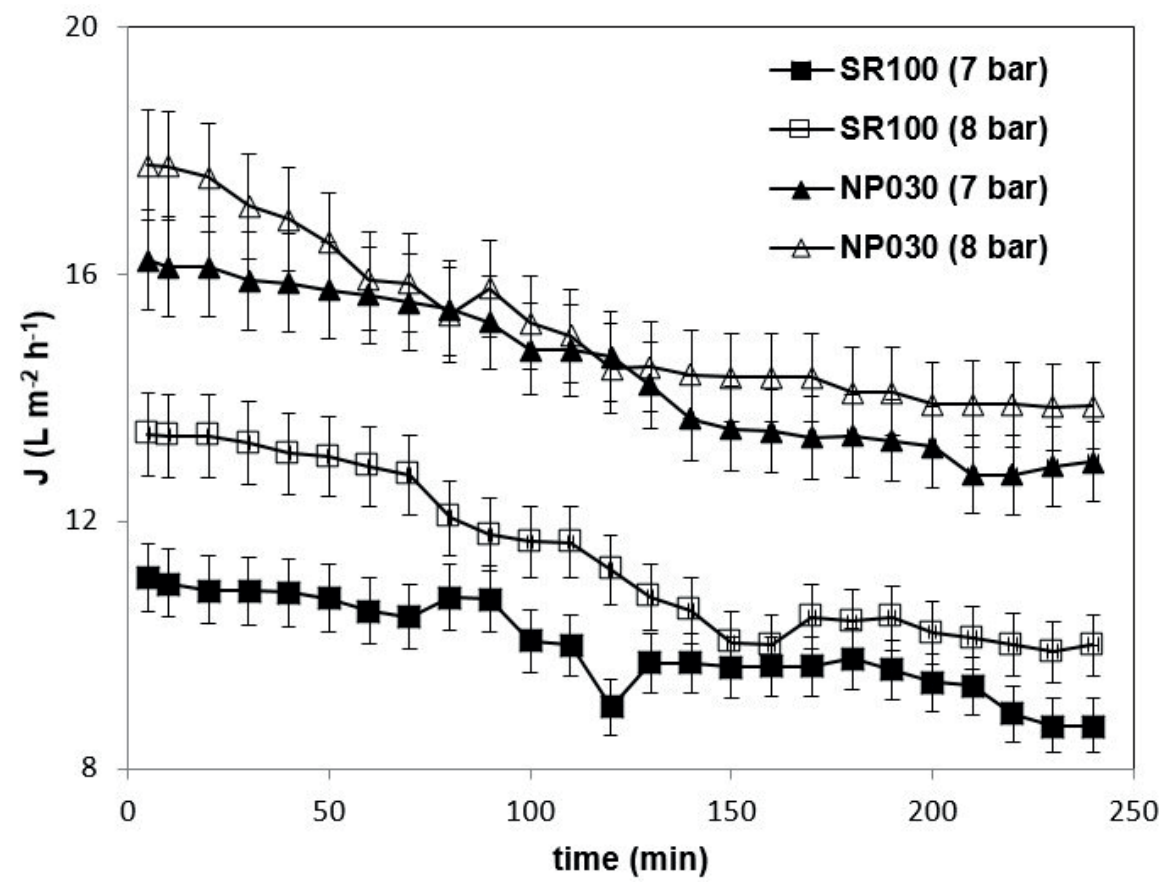

FIGURE 3: Monitoring of the permeate flux during the nanofiltration process with membranes SR100 and NP030, at 7 and 8 bar pressure. 
bar, after $1 \mathrm{~h}$ of system operation. Figure 4 shows the permeate flux values obtained in the filtration process with the membranes SR100 and NP030 at 7 and 8 bar at 30, 60, 90 and $120 \mathrm{~L} \mathrm{~h}^{-1}$ recirculation flow rates.

In the NF process of this study, not only for the SR100 membrane, as for the NP030 membrane, the variation of the recirculation flow rate of the system had little influence on the permeate flux values obtained. Tavares and Brião (2012) evaluated the effect of pressure and tangential velocity on the permeate flux in a spiral-type filtration system and observed that the higher the pressure and the tangential velocity of the system, greater the permeate flux. It was observed that in this work, probably due to the high range of the recirculation flow rate of the system, little influence was exerted on the values of tangential velocities and, consequently, the variation of the permeate value of the process was negligible. Probably, in a range of variation of the recirculation flow smaller, there will be a greater impact on the values of the tangential velocities and consequently of the permeate flux.

Finally, the membrane separation process was batch operated, where the permeate stream was collected until a determined VRF defined in this study as 2.5, operated for about $8 \mathrm{~h}$ at a pressure of 8 bar, the pressure of NF step was maintained at 8 bar due to the system's technical constraints, and a recirculation flow rate of $30 \mathrm{~L} \mathrm{~h}^{-1}$. Figure 5 shows the permeated flow as a function of the VRF.

It was observed that, during the filtration process, up to $60 \%$ yield, the permeate flux of the nanofiltration process with the SR100 membrane presented a 33\% reduction, while for the NP030 membrane the permeate flux drop was $25 \%$ approximately. Membrane fouling phenomena can be investigated by monitoring the water permeability (Cingolani et al., 2018). The membrane permeability varied throughout the process, between 1.58-1.23 $\mathrm{L} \mathrm{m}^{-2} \mathrm{~h}^{-1}$ bar $^{-1}$ (SR100) and 2.33-1.95 $\mathrm{L} \mathrm{m}^{-2} \mathrm{~h}^{-1}$ bar $^{-1}$ due to the degree of membrane fouling during the continuous operation. The initial hydraulic permeability of the membrane (new membrane) was 1.70 (SR100) and $2.38 \mathrm{~L} \mathrm{~m}^{-2} \mathrm{~h}^{-1}$ bar $^{-1}$ (NP030). A cleaning process could be applied to try to recover the permeate flux of the NF and to minimize the fouling of the membranes (Rukapan et al., 2012).

Table 3 presents the values of the parameters of pretreated leachate and effluent after the application of the NF under operational conditions defined.

The concentration of HS was considerably reduced and their final value corresponded to a reduction of $90 \%$ and $87 \%$ of the concentration present in the pretreated leachate, given the filtration process with membranes SR100 and NP030, respectively.

According to Baker (2012), the nanofiltration process is inefficient in the removal of salts, since it is able to retain molecular species with molar mass varying between 500 and $2000 \mathrm{Da}$, even though, it was observed percentages of removal of $\mathrm{Cl}^{-}$higher than $40 \%$ after the NF. Amaral et al. (2015) reported chloride removal percentages of $84 \%$ and $90 \%$ of conductivity after the application of NF. Baker (2012) points out that chloride is a monovalent anion, and the removal of this type of ion is not characteristic of the nanofiltration membrane. However, its removal can occur due to the precipitation of chloride ions in the membrane, or even by the transport of ions, in order to maintain the membrane electroneutrality. In complex aqueous matrices, such as effluents, the presence of a wide variety of ions also presents a wide variety of complex interactions. In order to maintain the electroneutrality, other ions are also retained or otherwise forced through the membrane, depending on the ionic forces involved (Amaral et al., 2015; Renou et al., 2008).

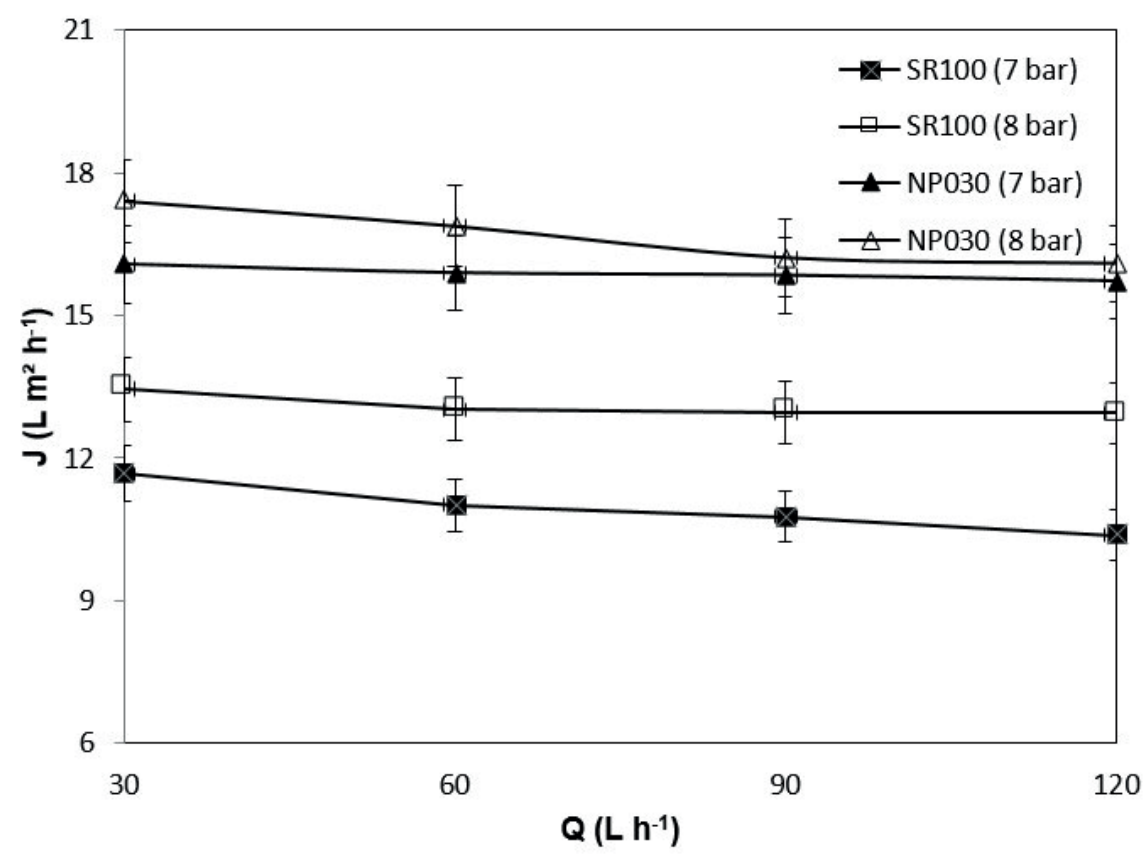

FIGURE 4: Permeate flux obtained in the filtration process with membranes SR100 and NP030 at 7 and 8 bar in recirculation flows of 30 , 60,90 and $120 \mathrm{Lh}^{-1}$. 


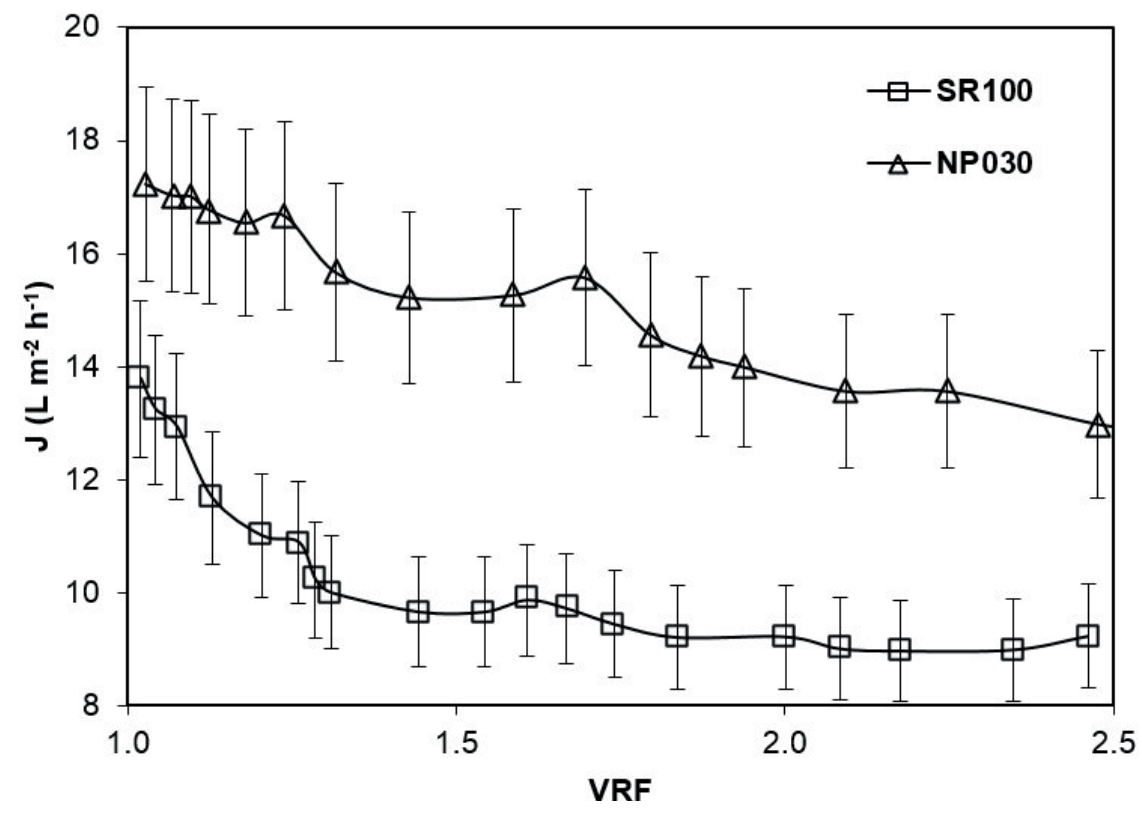

FIGURE 5: Variation of the permeate flux as a function of the VRF of the nanofiltration process (Operating pressure of 8 bar, recirculation flow of $30 \mathrm{Lh}^{-1}$ and $5 \mathrm{~h}$ of operation).

\subsection{Hybrid process}

Table 4 shows the results of the parameters of raw leachate, treated leachate in optimum lime concentration (30 $\left.\mathrm{g} \mathrm{L}^{-1}\right)$, air stripping (1.33 L air.min ${ }^{-1}$ per liter effluent and time 24h hydraulic retention) and nanofiltration with SR100 and NP030 membranes (8 bar operating pressure and $30 \mathrm{~L} \mathrm{~h}^{-1}$ recirculation flow).

The application of lime was efficient in the removal of recalcitrant organic matter, true-color, and $\mathrm{NH}_{3}-\mathrm{N}$. The concentration of $\mathrm{COD}, \mathrm{HS}$, and the true color was reduced to concentrations of $2258 \pm 232 \mathrm{mg} \mathrm{L}^{-1}, 821 \pm 80 \mathrm{mg} \mathrm{L}^{-1}$ and $1290 \pm 107 \mathrm{mg} \mathrm{Pt}^{-C o} \mathrm{~L}^{-1}$, respectively. The concentration of $\mathrm{NH}_{3}-\mathrm{N}$, through the proposed pretreatment, was reduced to a concentration compatible with the disposal limit established by local legislation.

In addition, it was observed that the application of the
NF process, after the physicochemical treatment, was efficient as a complementary step to remove the effluent pollution parameters. The combined treatment process with the SR100 membrane showed percentage removals of COD, SH, ABS $254 \mathrm{~nm}$, true-color and ammoniacal nitrogen of $96 \%, 94 \%, 89 \%, 99 \%$, and $99 \%$, respectively. On the other hand, with the NF030 membrane, removal percentages were $94 \%, 93 \%, 89 \%, 98 \%$, and $99 \%$, respectively, for the same parameters. These results are comparable with Smol and Wlodarczyk-Makula (2016) that studied an integrated system of coagulation-NF/RO.

\subsection{Economical aspect}

Regarding cost estimates for the process, the information obtained from the experimental units was used to carry out an initial survey of the project variables and

TABLE 3: Physico-chemical parameters of pretreated leachate and effluent after the application of the nanofiltration $(n=3)$.

\begin{tabular}{|c|c|c|c|c|c|c|c|c|c|}
\hline \multirow{3}{*}{ Parameters } & \multirow{2}{*}{\multicolumn{3}{|c|}{ Pre-treated leachate }} & \multicolumn{6}{|c|}{ Nanofiltration } \\
\hline & & & & \multicolumn{3}{|c|}{ SR100 } & \multicolumn{3}{|c|}{ NP030 } \\
\hline & Min & Max & Average $\pm \sigma$ & Min & Max & Average $\pm \sigma$ & Min & Max & Average $\pm \sigma$ \\
\hline $\mathrm{pH}$ & 10.7 & 11.5 & $11.1 \pm 0.1$ & 7.8 & 8.3 & $8.0 \pm 0.1$ & 7.9 & 8.2 & $8.1 \pm 0.1$ \\
\hline $\operatorname{COD}\left(\mathrm{mg} \mathrm{L}^{-1}\right)$ & 2116 & 2368 & $2258 \pm 226$ & 174 & 205 & $193 \pm 19$ & 220 & 278 & $249 \pm 25$ \\
\hline $\mathrm{HS}\left(\mathrm{mg} \mathrm{L}^{-1}\right)$ & 782 & 866 & $821 \pm 80$ & 75 & 98 & $84 \pm 8$ & 95 & 121 & $109 \pm 10$ \\
\hline Abs 254 nm & 12.98 & 13.38 & $13.25 \pm 0.20$ & 2.46 & 3.44 & $2.88 \pm 0.10$ & 2.55 & 3.07 & $2.87 \pm 0.10$ \\
\hline $\mathrm{NH}_{3}-\mathrm{N}\left(\mathrm{mg} \mathrm{L}^{-1}\right)$ & 10.9 & 18.5 & $14.8 \pm 1.0$ & 7.9 & 10.2 & $8.9 \pm 1.0$ & 5.6 & 12.5 & $9.4 \pm 0.9$ \\
\hline $\begin{array}{l}\text { True color (mg } \\
\text { Pt-Co L-1) }\end{array}$ & 1120 & 1340 & $1290 \pm 121$ & 67 & 97 & $83 \pm 8$ & 110 & 135 & $122 \pm 12$ \\
\hline $\mathrm{Cl}^{-}\left(\mathrm{mg} \mathrm{L}^{-1}\right)$ & 523 & 632 & $585 \pm 55$ & 225 & 371 & $298 \pm 27$ & 302 & 343 & $318 \pm 29$ \\
\hline $\begin{array}{l}\text { Conductivity (mS } \\
\mathrm{cm}^{-1} \text { ) }\end{array}$ & 12 & 13 & $13 \pm 1$ & 6 & 7 & $7 \pm 1$ & 9 & 10 & $9 \pm 1$ \\
\hline Turbidity (NTU) & 36 & 45 & $39 \pm 4$ & 0.25 & 0.56 & $0.40 \pm 0.10$ & 0.50 & 1.10 & $0.77 \pm 0.10$ \\
\hline
\end{tabular}


TABLE 4: Parameters of raw leachate, lime application $\left(30 \mathrm{~g} \mathrm{~L}^{-1}\right)$, air stripping (1.33 $\mathrm{L}$ air min $\mathrm{m}^{-1}$ per liter of effluent and 24-hour hydraulic

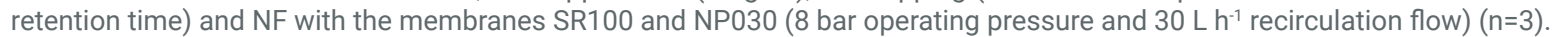

\begin{tabular}{|c|c|c|c|c|c|c|c|c|c|c|c|c|c|}
\hline \multirow{3}{*}{ Parameters } & \multirow{2}{*}{\multicolumn{3}{|c|}{ Raw leachate }} & \multirow{2}{*}{\multicolumn{3}{|c|}{$\begin{array}{l}\text { C-F/Air Striping } \\
\text { Lime }\left(30 \mathrm{~g} \mathrm{~L}^{-1}\right)\end{array}$}} & \multicolumn{6}{|c|}{ Nanofiltration } & \multirow{3}{*}{$\begin{array}{l}\text { Bra- } \\
\text { zilian } \\
\text { legis- } \\
\text { lation }\end{array}$} \\
\hline & & & & & & & \multicolumn{3}{|c|}{ SR100 } & \multicolumn{3}{|c|}{ NP030 } & \\
\hline & Min & Max & $\begin{array}{l}\text { Average } \\
\quad \pm \sigma\end{array}$ & Min & Max & Average $\pm \sigma$ & Min & $\operatorname{Max}$ & Average $\pm \sigma$ & Min & Max & Average $\pm \sigma$ & \\
\hline $\mathrm{pH}$ & 7.7 & 8,2 & $8.0 \pm 0.1$ & 10.7 & 11.5 & $11.1 \pm 0.1$ & 7.8 & 8.3 & $8.0 \pm 0.1$ & 8.0 & 8.3 & $8.1 \pm 0.1$ & $5-9$ \\
\hline $\operatorname{COD}\left(\mathrm{mg} \cdot \mathrm{L}^{-1}\right)$ & 4330 & 4690 & $4522 \pm 90$ & 2116 & 2368 & $2258 \pm 232$ & 174 & 205 & $193 \pm 21$ & 220 & 278 & $249 \pm 22$ & 250 \\
\hline $\mathrm{HS}\left(\mathrm{mg} \cdot \mathrm{L}^{-1}\right)$ & 1233 & 1543 & $1466 \pm 120$ & 782 & 866 & $821 \pm 80$ & 75 & 98 & $84 \pm 9$ & 95 & 121 & $109 \pm 11$ & - \\
\hline ABS $254 \mathrm{~nm}$ & 26.29 & 27.01 & $26.70 \pm 0.10$ & 12.98 & 13.38 & $13.25 \pm 1$ & 2.46 & 3.44 & $2.88 \pm 0.55$ & 2.55 & 3.07 & $2.87 \pm 1$ & - \\
\hline $\begin{array}{l}\mathrm{NH}_{3}-\mathrm{N}(\mathrm{mg} \\
\left.\mathrm{L}^{-1}\right)\end{array}$ & 1150 & 1851 & $1512 \pm 139$ & 10.9 & 18.5 & $14,8 \pm 0.8$ & 7.9 & 10.2 & $8.9 \pm 1$ & 5,6 & 12.5 & $9.4 \pm 1$ & 20 \\
\hline $\begin{array}{l}\text { True color } \\
\text { (mg Pt-Co L-1) }\end{array}$ & 5560 & 7640 & $6391 \pm 602$ & 1120 & 1430 & $1290 \pm 107$ & 67 & 97 & $83 \pm 7$ & 110 & 135 & $122 \pm 14$ & - \\
\hline $\mathrm{Cl}^{-}\left(\mathrm{mg} \mathrm{L}^{-1}\right)$ & 890 & 1327 & $887 \pm 67$ & 523 & 632 & $585 \pm 55$ & 225 & 371 & $298 \pm 30$ & 302 & 343 & $318 \pm 33$ & - \\
\hline $\begin{array}{l}\text { Conductivity } \\
\left(\mathrm{mS} \mathrm{cm}^{-1}\right)\end{array}$ & 14,57 & 20.45 & $19 \pm 4$ & 12.48 & 12.57 & $12.53 \pm 1$ & 6.34 & 7.21 & $6.85 \pm 0.7$ & 9.00 & 9.32 & $9.18 \pm 1$ & - \\
\hline $\begin{array}{l}\text { Turbidity } \\
\text { (NTU) }\end{array}$ & 110 & 120 & $110 \pm 15$ & 36 & 45 & $39 \pm 2$ & 0.25 & 0.56 & $0.40 \pm 0.05$ & 0.50 & 1.10 & $0.77 \pm 0.08$ & - \\
\hline
\end{tabular}

subsequent assessment of leachate treatment costs. Considering a means leachate generation flow of $1000 \mathrm{~m}^{3}$, nanofiltration process recovery efficiency of $60 \%$ and average permeate flux of $12 \mathrm{~L} \mathrm{~m}^{-2} \mathrm{~h}^{-1}$, the total cost per $\mathrm{m}^{3}$ of treated effluent was estimated in two scenarios, in which different membrane $\mathrm{m}^{2}$ prices of the used in the filtration process were considered.

The CAPEX of the leachate treatment system was US\$ $5.618 .661,80$ considering the cost of the polymer membrane of US\$ $40 \mathrm{~m}^{-2}$ presented by Baker (2012); Guerra and Pellegrino (2012), and US\$ 6.289.481,30 in the scenario in which the cost of $\mathrm{m}^{2}$ of membrane was US\$ 180, as pointed out by Amaral et al. (2016). It stands out, the proposed treatment does not present any biological processes, which in addition to increasing the costs of treatment of leachate, is inefficient in the treatment of effluents with a high concentration of recalcitrant organic matter. In addition, NF meets a growing demand in the area of leachate treatment - decentralized treatment plants - that is, land and construction costs are reduced, since membrane processes are compact systems and can be arranged in mobile structures, representing a reduction in the CAPEX.

Figure 6 shows the relative composition, in percentage, of CAPEX $(a, b)$ and OPEX (c, d), considering the cost of the membrane $\mathrm{m}^{2}$ presented by Baker (2004); Guerra and Pellegrino (2012) (a and c) and Amaral et al. (2016) (b and d), respectively.

CAPEX has highlighted the expenses with an installed system, which accounts for the acquisition of equipment, valves, pipes, and instrumentation. It should be noted that these costs are related to the $\mathrm{m}^{2}$ of the membrane used in the NF process. Regarding the OPEX, the percentage value related to the exchange of membranes stands out, $41.5 \%$ (Figure 7.c) and 39.2\% (Figure 7.d). Operating expenses are incurred over the life of the project and include a variable component that can be managed continuously, thus it is evident that good operational practices throughout the useful life of the leachate treatment plant, such as periodic cleaning of membranes, may reduce operating costs and make the proposed treatment process more economically attractive.

Figure 7 shows the total cost values per $\mathrm{m}^{3}$ of treated leachate for different periods of operation of the treatment plant.

Considering that the landfill would operate for 25 years and after closure, the leachate treatment plant would maintain its activities for another 15 years, over a period of 40 years, the total cost to treat the $\mathrm{m}^{3}$ of leachate would be US\$ 10.54 (scenario a) and USS\$ 11.33 (scenario b).

Regarding of leachate treatment in Brazil, considerable efforts have been made to implement efficient technologies for the removal of pollutants and achieve compliance with the standards established by environmental legislation (Costa et al., 2019). Also, it is important to note that the selection of the most suitable treatment technology for landfill leachate depends on the quality and quantity of leachate, age of landfill, plant flexibility and operation conditions (Talalaj et al., 2019). Economic parameters also play an important role in this decision-making process.

\section{CONCLUSIONS}

Due to the complexity of landfill leachate, to provide a treated effluent that can be discharged into natural water streams is not achievable using a single technique but a combination of different processes is required. In this study, the combined process allowed the production of a clear and colorless permeate and has proved to be very effective at removing all pollutants. The total cost to treat the leachate ranged from 10,5 to US\$ 12,80 . Regarding cost estimates for the process, it was verified that a treated effluent at a lower cost to that currently presented by the Seropédica landfill was obtained through the applied treatment. In addition, it was assumed that it would be possible to abdicate the biological processes currently employed at the 
CAPEX

(a)

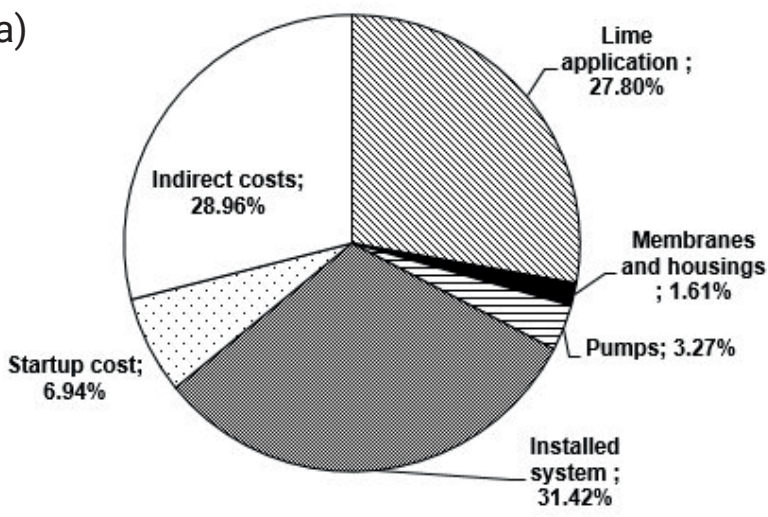

(b)

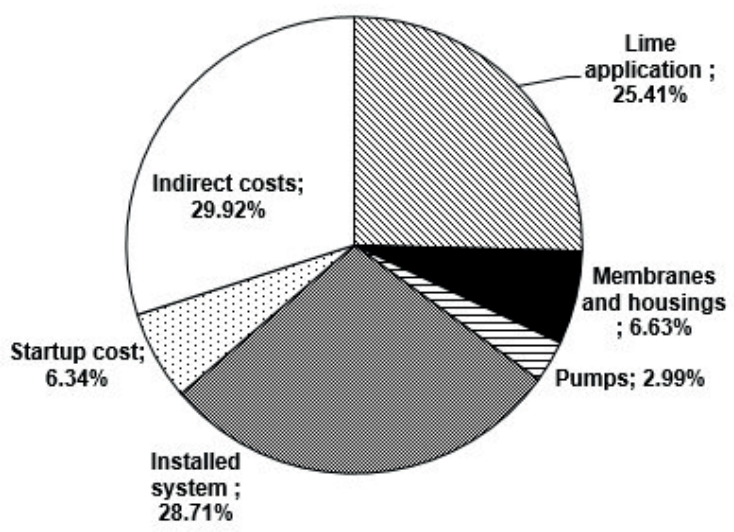

OPEX

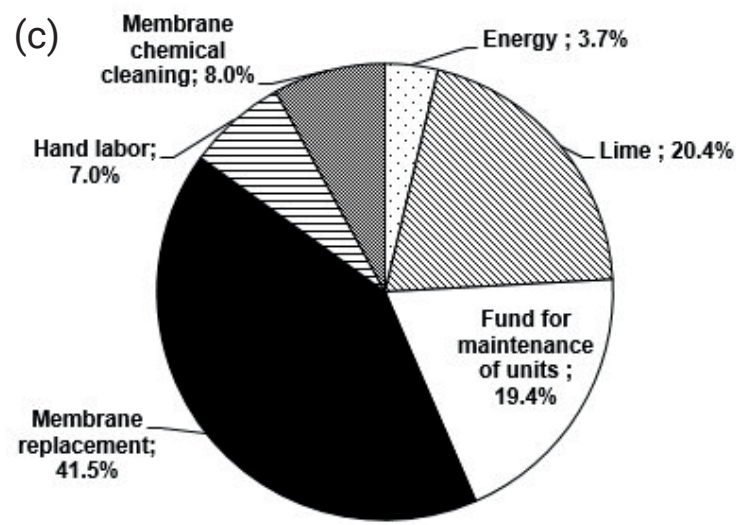

(d)

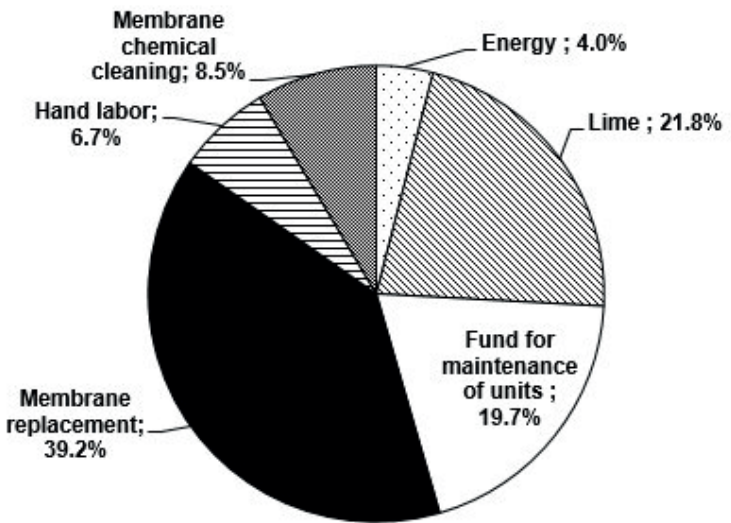

FIGURE 6: Relative composition, in percentage, of CAPEX (a, b) and OPEX (c, d). (a and c) Baker (2012); Guerra and Pellegrino (2012) membrane price; (b and d) Amaral et al. (2012) membrane price.

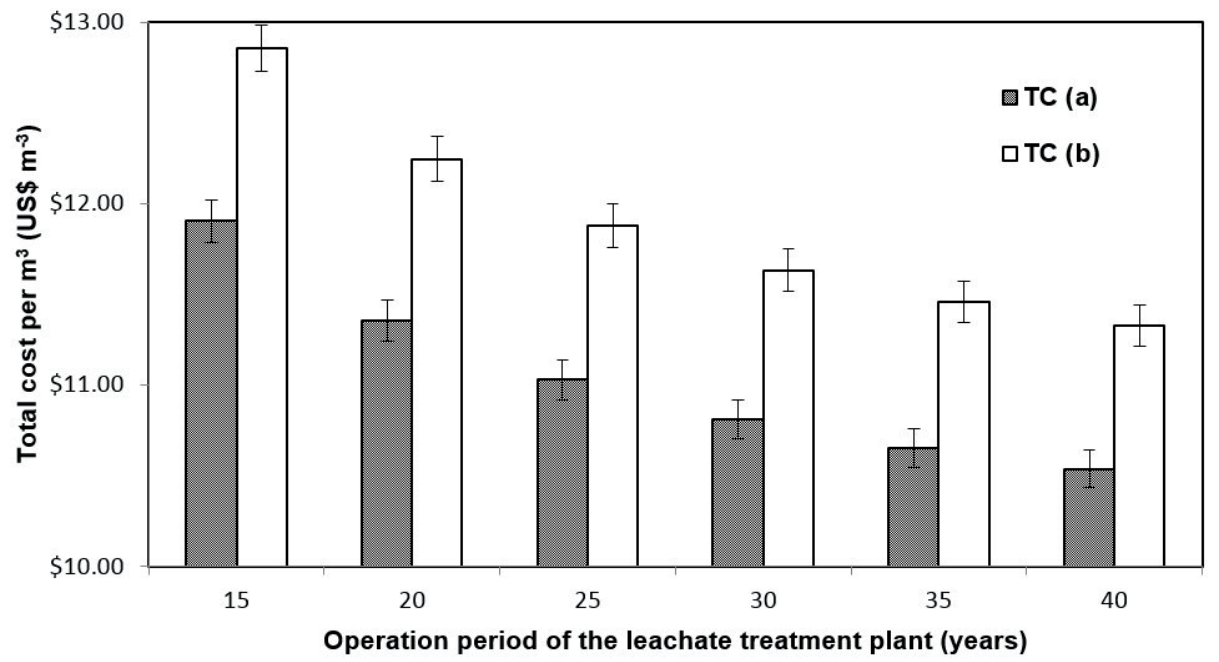

FIGURE 7: Total cost per $\mathrm{m}^{3}$ of treated leachate for different periods of operation of the nanofiltration treatment.

leachate treatment plant, using the proposed system under the conditions established. Future investigations should focus on the recovery of permeate flux of nanofiltration, minimizing the fouling of membranes and the destination of the sludge lime application and membrane concentrate.

\section{ACKNOWLED GMENTS}

The authors would like to thank Municipal Urban Cleaning Company (Rio de Janeiro city) for sending samples of leachates and also to express their gratitude to Brazilian National Council for Scientific and Technological Develop- 
ment (CNPq) (process 147737/2016-8) and Foundation for Research Support of the State of Rio de Janeiro (Faperj) (reference E-26/202.923/2018) for the financial support.

\section{REFERENCES}

Ahmed, F. N. and Christopher Q. (2012). Treatment of landfill leachate using membrane bioreactors: A review. Desalination, 287, 41-54. https://doi.org/10.1016/j.desal.2011.12.012

Amaral M. C. S., Pereira H. V., Nani E. and Lange L. C. (2015). Treatment of landfill leachate by hybrid precipitation/microfiltration/ nanofiltration process. Water Sci Technol, 72.2, 269-276. https:// doi.org/10.2166/wst.2015.218

Amaral, M. C. S., Moravia, W. G., Lange, L. C., Rico, M. R., Magalhães, N. C., Ricci, B. C., Reis, B. G. (2016). Pilot aerobic membrane bioreactor and nanofiltration for municipal landfill leachate treatment. J. Environ. Sci. Health, Part A., 51:8, 640-649. https://doi.org/10.108 0/10934529.2016.1159874

Amokrane, A., Comel, C., Veron, J. (1997). Landfill leachate pretreatment by coagulation-flocculation. Water Res., 31, 2775-2782. https://doi.org/10.1016/S0043-1354(97)00147-4

Amor, C., De Torres-Socías, E., Peres, J. A., Maldonado, M. I., Oller, I., Malato, S., Lucas, M. S. (2015). Mature landfill leachate treatment by coagulation/flocculation combined with Fenton and solar Photo-Fenton processes. J. Hazard. Mater., 286, 261-268. https://doi. org/10.1016/j.jhazmat.2014.12.036

APHA/ AWWA/ WEF. Standard Methods for the Examination of Water and Wastewater, 22nd. USA, APHA, 2012.

Aziz, H. A., Alias, S., Adlan, M. N., Faridah, Asaari, A. H., Zahari, M. S. (2007). Color removal from landfill leachate by coagulation and flocculation processes. Bioresour. Technol., 98, 218-220. https:// doi.org/10.1016/j.biortech.2005.11.013

Baker R. W. (2012). Membrane Technology and Applications. John Wiley \& Sons, United Kingdom, 3rd ed., 575 p.

Calabrò, P. S., Gentili, E., Meoni, C., ORSI, S., Komilis, D. (2018). Effect of the recirculation of a reverse osmosis concentrate on leachate generation: A case study in an Italian landfill. Waste Manage. 76, 643-651. https://doi.org/10.1016/j.wasman.2018.03.007

Campos, J. C., Moura, D., Costa, A. P., Yokoyama, L., Araujo, F. V. F., Cammarota, M. C. (2013). Evaluation of pH, alkalinity and temperature during air stripping process for ammonia removal from landfill leachate. J. Environ. Sci. Health., Part A., 48, 1105-1113. https:// doi.org/10.1080/10934529.2013.774658

Chaudhari L. B. and Murthy Z. V. P. (2010). Treatment of landfill leachates by nanofiltration. J Environ Manage., 91, 1209-1217. https://doi.org/10.1016/j.jenvman.2010.01.007

Chen G., Grasel, P., Millington, G., Hallas J., Ahmad H., Tawfiq, K., 2017. Chloride removal from landfill leachate by the ultra-high lime with aluminum process. J Urban Environ Eng 11:1, 3-8. https://doi. org/10.4090/juee.2017.v11n1.003008

Cingolani, D., Fatone, F., Frison, N., Spinelli M., Eusebi A. L. (2018). Pilot-scale multi-stage reverse osmosis (DT-RO) for water recovery from landfill leachate. Waste Manage., 76, 566-574. https://doi. org/10.1016/j.wasman.2018.03.014

Costa A. M., Alfaia R. G. S. and Campos J. C. (2019). Landfill leachate treatment in Brazil - An overview. J Environ Manage, 232, 110-116. https://doi.org/10.1016/j.jenvman.2018.11.006

De Almeida, R., Costa, A. M., Oroski, F. A., Campos, J. C. (2019). Evaluation of coagulation-flocculation and nanofiltration processes in landfill leachate treatment, J. Environ. Sci. Health., Part A 54(11), 1091-1098. doi: 10.1080/10934529.2019.1631093

Ehrig, H.-J., \& Robinson, H., 2010. Landfilling: Leachate Treatment Solid Waste Technology \& Management, 858-897. https://doi. org/10.1002/9780470666883.ch54

El-Gohary, F.A., Khater, M., Gamal Kamel, M. (2013). Pretreatment of landfill leachate by ammonia stripping. J. Appl. Sci. Res., 9, 39053913.

Golob, V., Vinder, A., Simonic, M. (2005). Efficiency of the coagulation/ flocculation method for the treatment of dyebath effluents. Dyes and Pigments, 67(2), 93-97. doi:10.1016/j.dyepig.2004.11.003

Guerra K. and Pellegrino J. (2012). Investigation of Low-Pressure Membrane Performance, Cleaning, and Economics Using a Techno-Economic Modeling Approach. U.S. Department of Interior, 127.

Ismail, I. M., Fawzy, A. S., Abdel-Monem, N. M., Mahmoud, M. H. El-Halwany, M. A. (2012). Combined coagulation flocculation pre treatment unit for municipal wastewater. Journal of Advanced Research, 3(4), 331-336. doi:10.1016/j.jare.2011.10.004
Lima L. S. M. S., Almeida R., Quintaes B. R., Bila D. M. and Campos J. C. (2017). Evaluation of humic substances removal from leachates originating from solid waste landfills in Rio de Janeiro State, Brazil. J. Environ. Sci. Health, Part A., 52, 828-836. https://doi.org/10.108 0/10934529.2017.1312182

Liu Z., Wu W., Shi P., Guo J. and Cheng J. (2015). Characterization of dissolved organic matter in landfill leachate during the combined treatment process of air stripping, Fenton, SBR and coagulation. Waste Manage., 41, 111-118. https://doi.org/10.1016/j.wasman.2015.03.044

Liu, B., Giannis, A., Zhang, J., Chang, V. W.-C., \& Wang, J.-Y. (2014). Air stripping process for ammonia recovery from source-separated urine: modeling and optimization. J. Chem. Technol. Biotechnol., 90 (12), 2208-2217. https://doi.org/10.1002/jctb.4535

Metcalf, E., Eddy, H., Tchobanoglous, G., Burton, F.L., Stensel, H.D. (2003). Wastewater Engineering: Treatment and Reuse, fourth ed. McGraw-Hill. https://doi.org/10.1016/0309-1708(80) 90067e6.

Postacchini L., Ciarapica, F. E., Bilivacqua, M. (2018). Environmental assessment of a landfill leachate treatment plant: Impacts and research for more sustainable chemical alternatives. J Clean Prod. 183, 1021-1033. https://doi.org/10.1016/j.jclepro.2018.02.219

Renou S., Poulain S., Givaudan J. G. and Moulin P. (2008). Treatment process adapted to stabilized leachates: Lime precipitation-prefiltration-reverse osmosis. J. Membr. Sci. 313, 9-22. https://doi. org/10.1016/j.memsci.2007.11.023

Renou, S., Poulain S., Givaudan J.G., Sahut, C., Moulin P. (2009). Lime treatment of stabilized leachates. Water Sci. Technol., 59:4, 673685. https://doi.org/10.2166/wst.2009.014

Robinson, A.H., 2005. Landfill Leachate Treatment, 6-12.

Rodrigues, F. S. F., Bila, D. M., Campos, J. C., Sant'anna Jr, G. L., Dezotti M., 2009. Sequential treatment of an old-landfill leachate. Int. J. Environ. Waste Manage. 4, 445-456. https://doi.org/10.1504/ IJEWM.2009.027408

Rukapan, W., Khananthai, B., Chiemchaisri, C., Chiemchaisri, W., 2012. Short- and long-term fouling characteristics of reverse osmosis membrane at full scale leachate treatment plant. Water Sci. Technol. 65 (1), 127-134. https://doi.org/10.2166/wst.2011.844

Salehi E., Madaeni S. S., Shamsabadi A. A. and Laki S., 2014. Applicability of ceramic membrane filters in the pretreatment of coke-contaminated petrochemical wastewater: Economic feasibility study. Cerami Inte. 40, 4805-4810. https://doi.org/10.1016/j. ceramint.2013.09.029

Schiopu A. M., Piuleac G. C., Cojocaru C., Apostol I., Mămăligă I. and Gavrilescu M. (2012). Reducing environmental risk of landfills: leachate treatment by reverse osmosis. Environ. Eng. Manage. j. 11, 2319-2331. doi:10.30638/eemj.2012.286

Serdarevic, A. (2018). Landfill Leachate Management - Control and Treatment. Advanced Technologies, Systems, and Applications II, Lecture Notes in Networks and Systems 28, https://doi. org/10.1007/978-3-319-71321-2_54

Silva, L.C., Reis, H. S., Afonso, B. W. Avaliação econômica de diferentes processos para remoção de amônia de lixiviados de aterros sanitários. Trabalho de Conclusão de Curso em Engenharia Química. 2011. 79 f. Escola de Química, UFRJ, RJ, 2011. (In Portuguese).

Singh N. and Cheryan M. (1998). Process Design and Economic Analysis of a Ceramic Membrane System for Microfiltration of Corn Starch Hydrolysate. J Food Eng. 38, 57-67. https://doi. org/10.1016/S0260-8774(98)00103-4

Sir M., Podhola M., Patocka T., Honzajkova Z., Kocurek P., Kubal M. and Kuras M. (2012). The effect of humic acids on the reverse osmosis treatment of hazardous landfill leachate. J Hazard Mater., 207-208, 86-90. https://doi.org/10.1016/j.jhazmat.2011.08.079

Smol, M., Włodarczyk-Makuła, M. (2016). Effectiveness in the removal of organic compounds from municipal landfill leachate in integrated membrane systems: coagulation - NF/RO. Polycycl. Aromat. Compd., 37, 456-474. https://doi.org/10.1080/10406638.2016.11 38971

Talalaj, I. A and Biedka, P. (2015). Impact of concentrated leachate recirculation on effectivenessof leachate treatment by reverse osmosis. Ecol. Eng., 85, 185-192. http://dx.doi.org/10.1016/j.ecoleng.2015.10.002

Talalaj, I. A., Biedka, P., Bartkowska I. (2019). Treatment of landfill leachates with biological pretreatments and reverse osmosis. Environmental Chemistry Letters. https://doi.org/10.1007/s10311019-00860-6 
Tavares C. R. G. and Brião V. B. (2012). Ultrafiltration of effluents from a dairy industry for nutrient recovery: effect of pressure and tangential velocity. J. Food Technol., 15:4, 352-362. http://dx.doi. org/10.1590/S1981-67232012005000028

Yao, P. (2013). Perspectives on technology for landfill leachate treatment. Arabian J. Chem. htpp://dx.doi.org/10.1016/j.arabjc.2013.09.031

Youcai, Z., \& Ziyang, L. (2017). General Structure of Sanitary Landfill. Pollution Control and Resource Recovery, 1-10. https://doi. org/10.1016/b978-0-12-811867-2.00001-7
Zawierucha I., Kozlowski C., Malina G. (2013). Removal of toxic metals ions from landfill leachate by complementary sorption and transport across polymer inclusion membranes. Waste Manage. 33, 2129-2136. https://doi.org/10.1016/j.wasman.2012.12.015

Zhang L., Lavagnoloc M. C., Baid H., Pivato A., Raga R., Yue D. (2019). Environmental and economic assessment of leachate concentrate treatment technologies using analytic hierarchy process. Resour Conserv Recy., 141, 474-480. https://doi.org/10.1016/j.resconrec.2018.11.007 